\title{
Speech Act Analysis of Whatsapp Statuses Used by Jordanians
}

\author{
Luqman Rababah \\ Correspondence: Luqman Rababah, School of Arts and Languages, Jadara University, Irbid, Jordan. P. O. BOX 733, \\ Postal Code 20110, Jordan.
}

Received: March 15, 2020

Accepted: April 22, 2020 Online Published: April 30, 2020

doi:10.5539/res.v12n2p28

\author{
URL: https://doi.org/10.5539/res.v12n2p28
}

\begin{abstract}
This qualitative study aims at investigating the WhatsApp statuses as used by Jordanians. It also investigates the types of speech acts used in these statuses. For this purpose, the study has collected and analyzed 200 statuses. The population of the study included all English language students of Jadadra University, where the sample of the study included (50) students, representing $20 \%$ of the whole population. The results showed that data were classified into six main topics; religious, social, political, personal, romantic and national. Additionally, five themes emerged from the data, namely, expressive, directive, assertive, commissive and declaration. Expressive speech acts represent (37\%) of the total speech acts types analyzed. The directive took the second place, representing (25\%) of the total status update analyzed. The assertive and commisive fall into the third and fourth position representing (23\%) and (15\%) respectively. The declarative type has the no occurrences representing $(0 \%)$ of the analyzed data. Some of the recommendations suggested are that further research needs to be conducted into the speech acts used by Jordanians on different social networking platforms.
\end{abstract}

Keywords: speech acts, WhatsApp, status

\section{Introduction}

With the invention of smartphones, the use of social media networking has prevailed the lives of people in the various age groups. It is now easier to review one's account on the social media anywhere and anytime one wishes to do so. The chance of communicating with others virtually has increased as the tool is available in one's pocket. For these reasons, it is now common to see people share photos, pictures, videos instantly to whom one wishes. This is because estimations indicated that most people in the developed countries are now having smartphones (Raiman, Antbring \& Mahmood, 2017).

Asserting this fact, Aljaad (2017) indicates that information and communication technology has become one of the most growing sector in the last few years as it represent a huge knowledge and technological progress aiming for providing access to different individuals wishing to access the latest developments around the world. It is, then, a form of knowledge revaluation due to the vast increase in using information and communication technologies. For this reason, it is a most that people should know the advantages provided by these moderns technologies so as they can capitalize their use for improving their will being.

In the same line of research, Al Ashmawy (2011) postulates that now a days humans are witnessing an era of information and technological revaluation as computers, internet has become a common scene in peoples' average lives. Additionally, information and communication technology and what they provide of tools has impacts the way of living in modern life. It is, therefore, logic to describe this era as a one dominated by the use of different communication tools to be an integral part of our lives.

In this aspect, Husni (2013) emphasize that the invention of smartphones has marked an information revolution is social media used as individual are no more forced to have a PC or a laptop to access the internet and be connected to the social media. As the new generation has grown up with the emergence of such technology, it has penetrated every human activity and this made it a key pillar in how people act in their daily lives.

Elaborating on this, Al Zamel (2014) argues that the invention of smartphones has provided new applications, and WhatsApp is one of them which has significantly impacted peoples' lives, especially in the Arab World. WhatsApp has revolutionized how people communicate and this started a war against traditional communication tools. As this application is mainly used on the different platforms provided at iPhone, Android or Windows Phone or even on some Nokia cell phones operating with Symbian, WhatsApp can send instant free massages, images and videos using various platforms, this advantage is one of the most important features in it leading to the enormous growing use of WhatsApp as one of the fastest developing social media platform in the last few years. 
Realizing that WhatsApp is a great threat to the pioneering social media websites and platforms (e.g. Facebook, Twitter, Myspace, Instagram). Facebook took over WhatsApp to make it one of its applications. Thus, WhatsApp has being the most growing social media platform in the last few years despite the fact it was only presented to the world a few years ago (Raiman, Antbring \& Mahmood, 2017). Hence, based on the issues discussed above, this current study identifies the following research questions to answer:

1. What are the most common types of WhatsApp statuses used by Jordanians?

2. What types of speech acts of WhatsApp statuses are used by Jordanians?

\section{Literature Review}

Literature review provides an overview of the related literature that covers the study scope and research questions. It also clarifies the theory of speech acts. The most current and relevant references and sources were presented in section.

This study made use of Searle theory of speech acts. Searle (1969) classifies the speech acts into five types. They are declaratives, expressive, directive, comissive and assertive. Declaratives are the speech acts that change the world via their utterance (blessing, announcing, arresting, naming, marrying, firing, dismissing,...). Representatives are the speech acts that state what the speaker believes to be the case or not (statement, assertion, conclusion, description, claim, report, hypothesis,...). Expressives are the speech acts that state what the speaker feels (pleasure, pain, likes, dislikes, joy, sorrow, greetings, apologies, congratulations, condolences, thanks, wish, complaint, compliment, leave taking, saying goodbye, admiration, irony, mocking, ...). Directives are the speech acts that speakers use to get someone else to do something (orders, commands, requests, suggestions, asking, advice, giving permission, giving way, warning, offer, complaint, threat, urge, challenge, invitation,...). Commissives are the speech acts that speakers use to commit themselves to some future action (promises, vow, threats, refusals, acceptation, offers, ...).

\section{Related Studies}

Several empirical studies are discussed in this section to clarify the reader's understanding of previous related research and also to understand where this study started from and to show the gaps in the existing studies (Al-Smadi, 2017; Banikalef \& Rababah, 2018; Mohamad et al., 2018; Raiman et al., 2017).

To start with, Mohamad et al., (2018) studied the speech acts in Facebook status updates posted by an apostate of Islam. The Facebook timeline was observed for a duration of two years (January 2015 to December 2016). More than 4000 postings were made in the data collection period. However, only 648 postings are related to apostasy. The data were classified according to the types of speech acts. Expressive speech act is the most frequent speech act $(33 \%, \mathrm{n}=215)$, followed by the directive $(27 \%, \mathrm{n}=177)$, assertive $(22 \%, \mathrm{n}=141)$, and commissive $(18 \%, \mathrm{n}=115)$, respectively.

Additionally, Faizin, Ramdhani, Gunawan \& Gojali (2018) elaborate the use of speech acts in the whatsapp status message. The study is a qualitative content analysis which applied a sample population covering a total number of 86 status messages posted by 23 participants taken in 4 consecutive days. The sample consisted of 13 male (56.52\%) and 10 female $(43.48 \%)$ from various social and educational background who ranged in age from 14 to 50 years old.

Similarly, Wulandari (2014) conducted a descriptive qualitative study in which she aimed at identifying the types of speech act and describing the functions of each type of the speech act on facebook statuses. The results showed that firstly based on the types of speech act. From 160 data the researcher finds five types of speech act, which are representatives act, 34 data or $21,25 \%$, directives act, 8 data or 5,00\%, commissives act, 64 data or $40,00 \%$, expressives act, and 1 datum or $0,62 \%$, declarations act.

In Jordan, Al-Smadi (2017) carried out a study that aimed at investigating the WhatsApp statuses as used by Jordanian people from a sociolinguistic perspective. To achieve this goal, 400 statuses were collected from Jordanian males and females who are divided into two main age groups, above and under 30 year's age. Then, the data were analyzed quantitatively and categorized based on the main following topics; religious, social, political, economic and fixed statuses. The results show the religious statuses are the most frequently used topic by Jordanian females whereas the social statuses are the most frequently used topic by Jordanian males. Moreover, the political and economic statuses are the least frequent statuses used among Jordanian. Furthermore, the results show that the most frequently used topic among males who are above 30 years old is the fixed statuses suggested by the mobile itself whereas the most frequently used topic among males who are under 30 years old is the social topic.

Although many studies have been carried out on social media (Faizin et al., 2018; Mohamad et al., 2018) most of these studies were not carried in either speech acts (Dastrjerdi \& Nasri, 2013) or in WhatsApp statuses (Faizin et al., 2018; Mohamad et al., 2018). In other words, studies dedicated to WhatsApp statuses are lacking in the region and specifically in the Jordanian context (Al-Smadi, 2017; Almwajeh \& Rababah, 2019). Thus, this study is to fill the gap found in the previous literature. 


\section{Methods}

The study employs a qualitative method design where the researcher has collected a number of WhatsApp status updates using a sample population covering a total number of 200 WhatsApp status updates posted by 50 participants taken in two month (January - February, 2020). To answer the research questions of the study, the study has made use of Critical Discourse Analysis (CDA). The population of the study included all English language students of Jadadra University, where the sample of the study included (50) students, representing $20 \%$ of the whole population. The respondents were informed about the objectives of the study and were ensured that all data obtained from them will be only used for academic research purposes.

\section{Results and Discussion}

In order to achieve the aims of the study, this section presents the findings based on the tools used to answer the following research questions:

1. What are the most common types of WhatsApp statuses used by Jordanians?

2. What types of speech acts of WhatsApp statuses are used by Jordanians?

Question One: What are the most common types of WhatsApp statuses used by Jordanians?

To answer the first question, the study has made use of CDA to find out the most common uses of WhatsApp status among Jordanians as shown in table 4.2.

Table 4.1. The most common uses of WhatsApp status among Jordanians ( $\mathrm{N}=200)$

\begin{tabular}{|l|c|c|}
\hline \multicolumn{1}{|c|}{ Status/theme } & F & \% \\
\hline Religious & 60 & 30 \\
\hline Social & 44 & 22 \\
\hline Personal & 34 & 17 \\
\hline Romantic & 30 & 15 \\
\hline Political & 16 & 8 \\
\hline National & 8 & 4 \\
\hline Sport & 8 & 4 \\
\hline Total & 200 & $100 \%$ \\
\hline
\end{tabular}

Table 4.1 shows that religious are the most frequent statuses used by the participants, followed by social, personal, romantic, political, national, and sport. Religious have a total of 60 occurrences, representing (30\%) of the total status update analyzed. The social have 44 incidents, representing (22\%) of the total status update analyzed. The National and social have the least appearances and they both have 8 occurrences each, representing (4\%) of the analyzed data.

Speaking of the religious statuses, this may refer to that Jordan is a Muslim Arab country and religiosity is high among Jordanians. The social statuses, which fall in the second place, show that Jordanians like to share their own status and personal information and they are keen to knowing the responses of other people on their status and what they share. Additionally, as youth are always searching for their own personality and forming identity as the most of university students in their late adolescences which is a time period for identity information and the approval of other people signifies that the individual is accepted or rejected on the personal level. The results of this research question are consistent with the previous studies made by (Al-Smadi, 2017; Banikalef \& Rababah, 2018)

Question two: What types of speech acts of WhatsApp statuses are used by Jordanians?

To answer the second research question and to find out the types of speech acts of WhatsApp statuses used among Jordanians, two hundreds of WhatsApp statuses have been analyzed using CDA. Through the analysis of data five themes and their sub-themes were noted. The themes were directive, declaration, comissive and expressive as shown in Table 4.2.

Table 4.2. Types of speech acts found in WhatsApp status updates $(n=200)$

\begin{tabular}{|l|l|}
\hline Theme/type & $\%$ \\
\hline expressive & 37 \\
\hline directive & 25 \\
\hline assertive & 23 \\
\hline comissive & 15 \\
\hline declarative & 0 \\
\hline Total & 100 \\
\hline
\end{tabular}

Table 4.2 shows that expressive are the most frequent speech acts used, followed by directive, assertive commissive, and 
declaration. Expressive speech acts represent (37\%) of the total speech acts types analyzed. The directive took the second place, representing (25\%) of the total status update analyzed. The assertive and commisive fall into the third and fourth position representing (23\%) and (15\%) respectively. The declarative type has the no occurrences representing $(0 \%)$ of the analyzed data.

The expressive have been expressed by the participants who usually use this type of speech acts in their daily lives. Taking the highest percentage of them all, the expressive are speech acts that state what the speaker feels and enable an individual to express his/her feelings, emotions, and opinions virtually. This finding is consistent with the results found in the earlier studies (e.g. Wulandari, 2014; Mohamad et al., 2018). The analysis of the data collected positioned directive the second place in the second position of the most frequent used speech acts. To make their friends react to their statuses, the participants usually make use of this type of speech acts. The results also go in the same line of the previous studies which were carried out by (Al-Smadi, 2017; Jdaitawi et al., 2011).

Furthermore, the assertive and commisive fall into the third and fourth places respectively. The participants which made use of the assertive types intend to bring the reader/ listener attention to their speakers' psychological states. The finding of assertive is contrary to a study made by (Faizin et al., 2018). On commisive, the Whatsapp users encounter self-commitment in their daily interaction and they are likely to share them with WhatsApp contacts. The results come in the same line with the previous studies (Wulandari, 2014; Mohamad et al., 2018). However, the declarative has zero incident made by the participants. This is consistent with the previous studies (e.g. Wulandari, 2014; Mohamad et al., 2018).

\section{Conclusion and Recommendations}

This qualitative study aims at investigating the WhatsApp statuses as used by Jordanians. It also investigates the types of speech acts used in these statuses. Studies dedicated to WhatsApp statuses are lacking in the region, specifically in the Jordanian context (Al-Smadi, 2017; Almwajeh \& Rababah, 2019). Thus, this study is to fill the gap found in the previous literature. To answer the research questions of the study, the study has made use of Critical Discourse Analysis (CDA). The results emerged from the first question were six main topics; religious, social, political, personal, romantic and national. The second research question has revealed five themes, namely, expressive, directive, assertive, commissive and declaration. Some of the recommendations suggested are that further research needs to be conducted into the speech acts used by Jordanians on different social networking platforms.

\section{References}

Al-Smadi, A. M. (2017). Gender and Age Patterns on WhatsApp Statuses as Used by Jordanians: A Sociolinguistic Perspective. International Journal of English Linguistics, 7(4), 56-66. https://doi.org/10.5539/ijel.v7n4p56

Almwajeh, M., \& Rababah, L. (2019). There is more to it than meets the eye: an intercultural study of religious speech acts between Jordanian and American students. International Journal of Linguistics, 11(1), 34-45. https://doi.org/10.5296/ijl.v11i1.14261

Al Zamel, N. (2014). Digital persons who changed our life. Fikr Journal, 9(1), 1-9.

Banikalef, A. A., \& Rababah, L. (2018). Gender differences and emotional expressiveness on Facebook: An analysis of prosodic features among Jordanian Facebookers. Studies in Linguistics and Literature, 2(3), 180-184. https://doi.org/10.22158/sll.v2n3p180

Dastrjerdi, H. V., \& Nasri, N. (2013). A cross-cultural study of speech acts: situational aspects of congratulations in English, Persian and Arabic. Global Journal of Foreign Language Teaching, 1(1), 15-22.

Faizin, B., Ramdhani, M. A., Gunawan, W., \& Gojali, D. (2018). Speech Acts Analysis in Whatsapp Status Updates. International Conference on Media and Communication Studies (ICOMACS 2018). https://doi.org/10.2991/icomacs-18.2018.46

Husni, M. (2013). The impact of training program for community responsibility development among a group of youth using Facebook. Education Journal, 22,48-60.

Jdaitawi, T., Ishak, N., Taamneh, A., Gharaibeh, N., \& Rababah, M. (2011). The effectiveness of emotional intelligence training program on social and academic adjustment among first year University students. International Journal of Business and Social Science, 2(24), 251-258. https://doi.org/10.5539/ijps.v3n2p135

Mohamad, A., Ab Rashid, R., Yunus, K., Rahman, S. B. A., Darus, S., Musa, R., \& Teh, K. S. M. (2018). Speech Acts in the Facebook Status Updates Posted by an Apostate. International Journal of English Linguistics, 8(4), 226-231. https://doi.org/10.5539/ijel.v8n4p226

Raiman, L., Antbring, R., \& Mahmood, A. (2017). WhatsApp messenger as a tool to supplement medical education for 
medical students on clinical attachment. BMC Medical Education, $17(1), \quad 7$. https://doi.org/10.1186/s12909-017-0855-x

\section{Copyrights}

Copyright for this article is retained by the author(s), with first publication rights granted to the journal.

This is an open-access article distributed under the terms and conditions of the Creative Commons Attribution license (http://creativecommons.org/licenses/by/4.0/). 